Scientific Journal Warsaw University of Life Sciences - SGGW

Problems of World Agriculture volume 19 (XXXIV), number 1, 2019: 120-132

DOI: 10.22630/PRS.2019.19.1.11

Agnieszka Tul-Krzyszczuk ${ }^{1}$, Pawel Jankowski ${ }^{2}$

Warsaw University of Life Sciences - SGGW, Poland

\title{
The Impact of Innovation on the Global Competitiveness of Polish Meat and Dairy Enterprises ${ }^{3}$
}

\begin{abstract}
The aim of the study was to analyse innovations implemented in the milk and meat industries, and their impact on increasing competitiveness. The study showed that the 2010-12 period saw the most product and process innovations being introduced. On the other hand, innovations in marketing were found to be more popular in 2013. Three groups of similar innovations were distinguished. The milk industry stood out when it comes to the extent of innovations implemented. Fewer innovations were found in the poultry meat industry. Beef and pork meat processing was the least innovative. The innovativeness of enterprises is greater with larger numbers of employees and the increase in scope of their field of operation. The implementation of innovations resulted in: improvement of the quality of goods (services), increase in stock, productive capabilities and revenues from sales, emergence of new markets, increase in competitiveness and prestige of the firm. Those are confirmed by the very good performance of foreign trade and better competitiveness rates of Polish meat producers.
\end{abstract}

Key words: innovation, competitiveness, meat, dairy, enterprise, global market, Poland

JEL Classification: L1, M31, L81, O31

\section{Introduction}

The ability to design and implement innovations is fundamental in any economic activity, as it constitutes progress and determines its economic dynamic on global markets. Innovativeness of enterprises in the context of competitiveness is a consequence of seeking improved fulfilment of needs of both individuals and groups, as well as more effective ways to operate on ever-changing markets. Moreover, it helps in achieving competitive advantage by, among others, improvement in quality of goods and services, relative reduction of costs and possibly maximisation of profits and thus a bigger share of the market.

The available source literature does not mention one specific definition of competitiveness. For the purpose of this article, the competitiveness shall focus on product and service innovations offered by economic entities. It can be thus defined as the ability of a firm to design, produce and sell goods and services that are better than those offered by the competitors. Furthermore, it means capability of achieving and maintaining its competitive position on the market. Hence, competitiveness is a characteristic feature of

${ }^{1}$ PhD Eng., Department of Organization and Consumption Economics, Faculty of Human Nutrition and Consumer Sciences, Warsaw University of Life Sciences - SGGW, 166 Nowoursynowska Street, 02-787 Warszawa, e-mail: agnieszka_tul_krzyszczuk@sggw.pl; https://orcid.org/0000-0002-6732-0346

${ }^{2} \mathrm{PhD}$, Department of Econometrics and Statistics, Faculty of Applied Informatics and Mathematics,

Warsaw University of Life Sciences - SGGW, 166 Nowoursynowska Street, 02-787 Warszawa, e-mail: paweł jankowski@sggw.pl; https://orcid.org/0000-0002-3176-8798

3 Research was realized within the project "BIOFOOD"- innovative, functional products of animal origin No. POIG.01.01.02-014-090/09 co-financed by the European Union from the European Regional Development Fund within the Innovative Economy Operational Programme 2007-2013 
only certain entities which effectively compete, stand put on the market and are able to survive and progress in a competitive environment.

The study aims to analyse the innovative activity of enterprises specializing in meat and milk processing, in the context of building up competitiveness on the global market. Two hypotheses were put forward:

1. The innovational activity of the meat and dairy enterprises is usually limited to changes to products and services. The scope and direction of those activities in enterprises are diversified in terms of industry, field of primary business operation and the size of the enterprise. Further, on that basis, groups of innovations in enterprises can be isolated.

2. The main reason behind the innovational activity of meat and dairy enterprises is improvement in productive capabilities and stock, and the quality of manufactured goods, which generates greater profits and increase share or prestige of the firm, in turn leading to better competitive position on the market.

The presented study is another step to develop research aimed at designing a model of innovativeness of enterprises operating in the gastronomic sector for the purpose of increasing competitiveness on the market.

\section{Innovativeness and competitiveness of gastronomic enterprises}

Innovativeness can be analysed at three levels: macroeconomic (innovativeness of the economy), mesoeconomic (innovativeness of the industry) and microeconomic (innovativeness of the enterprise). Source literature underlines the significant role of innovations that make each entity competitive. Enterprises which implement innovations, especially technological ones, are more profitable than those which do not invest in innovation. These firms achieve: lower costs of operation, diversification and expansion of the goods and services produced, improved quality of existing products and services. Providing the consumer with desirable and innovative products by the enterprise secures its position on the market or increases its share on the market as well as reinforces its standards. This in turn leads to higher revenues from sales and accordingly, increased competitiveness. Combining new technology with new production techniques allows maximisation of efficient production.

Competitiveness means the ability to produce new goods or services, to achieve success in economic competition and to effectively develop in the long term. In the face of globalisation and increasing consumer awareness, competitiveness is equal to comparing firms, industries or sectors, with the products and services that they offer, and which cooperate and/or compete in a given place (physical or virtual) in order to achieve common economic or trade goals. In addition, according to the OECD definition, competitiveness means the ability of regions, nations or supranational clusters to stand against international competition. Competitiveness provides a relatively high rate of return of the components of production and relatively high employment. Increase in productivity is crucial to improving competitiveness on international markets, in order to achieve long-term improvement of quality of life and to create new jobs (Tłuczak, 2017)

An enterprise's competitiveness is a multidimensional characteristic of a company, resulting both from its internal properties and the ability to deal with external conditions coming from the environment. Conducting its business in an efficient and an effective way, 
enables a firm to achieve the objectives established in its business strategy (Flak and Hunger, 2009; Szopik, 2007). The competitiveness of the sector may be defined as the ability to cope with international competition, expressed in the maintenance of a significant amount of exports, but also the ability to maintain a high level and pace of development of the internal market (Tereszczuk, 2018).

In 2010, annual production of poultry meat in Poland amounted to 1,386 thousand tons of meat, whereas in 2016 this number grew to 2,267 thousand tonnes (increase by $63.6 \%$ ). The increase in poultry production contributed to the Polish leadership position in this category of production in Europe. The second position is the pork production (4th place in the EU), which since 2010 has increased from 1516 thousand tons to 1607 thousand tonnes in 2016. The smallest increase (by 97 thousand tonnes) in production was recorded on the beef market, which currently fluctuates at the level of 470 thousand tonnes (Multański, 2018).

With Poland's accession to the EU in 2004, the economic conditions for Polish food processors changed as they gained free access to a large, developed and demanding European market.

In order to capitalize on the possibilities of exporting food to the markets of these countries depended on the competitiveness of Polish products and their acceptance by EU consumers. It is estimated that in 2017 the share of Polish exports of agri-food products amounted to $13.4 \%$ and imports $9.3 \%$. Similarly, the share of export value in the value of sold production for the Polish food industry in 2017 was about $40 \%$ (against $13-14 \%$ before Poland's accession to the EU) (Tereszczuk, 2018).

According to the calculations of the Ministry of Finance, the value of food exports from Poland increased by EUR 22 billion (which gives a 421\% increase) from 2004 to 2017. Last year, the value of Polish exports of agri-food products reached a record level of EUR 27.3 billion, an increase of $12 \%$ annually. Over 80 percent of the export of food products from Poland (in PLN) goes to the European Union, including Germany, Great Britain and the Netherlands (Fryc, 2018; Szajner, 2018). However, the data of the Institute of Agricultural and Food Economics indicate that in the first half of 2018, the value of exports reached 13.9 billion euros and was 5.3 percent higher than the previous year. The value of imports amounted to EUR 9.7 billion and increased by 2.4 percent. The excess of exports over imports has increased from 3.7 to 4.1 billion euros. The foreign trade of agrifood products is dominated by processed food (Szajner, 2018).

In the first half of 2018, 715 thousand tons of reddish meat were exported (i.e. 3\% more than a year earlier), thus gaining 1.9 billion PLN (6\% more). There was also a significant increase in poultry export (by 15\%), reaching 628 thousand tones. The value of sales amounted to PLN 1.1 billion (22\% more), which implied strong growth dynamics. Many markets, closed as a result of the detection of a bird flu virus in Poland in 2017, reopened for Polish poultry. Export accounted for $42.6 \%$ of industrial production of poultry meat produced in large facilities. On the other hand, export of beef products amounted to 276.2 thousand tonnes in product weight and was $3.0 \%$ higher than in the same period of the previous year. With volume growth, exports in value terms increased by $15.3 \%$ to EUR 996.6 million. The positive balance of foreign trade in beef products increased to EUR 897.2 million (Szajner, 2018).

In the case of the dairy industry, the results of foreign trade in January-July 2018 were better than in the corresponding period of 2017. Export increased by $6.1 \%$ to approx. 2.68 billion liters of raw milk as a result of the increase in butter exports (by 19.7\%), milk powder (by $12.9 \%$ ) and cheese and curd (by 6.7\%). Imports also increased (by $7.2 \%$ to 
approx. PLN 1.11 billion). As a result, the surplus of exports over imports of milk products increased by $5.4 \%$ to approx. PLN 1.57 billion in the commodity equivalent. Valuable revenues from exports of dairy products increased by $1.0 \%$ to approx. EUR 1.33 billion. The largest revenues came from the sale of butter (by $31.1 \%$ ), which resulted not only from the volume of exports more than the previous year, but also by $9.5 \%$ higher transaction prices. Expenditure on imports of dairy products increased by $1.7 \%$ to 575.7 million EUR, which means that the value of the positive trade balance in the period rose by only $0.4 \%$ to EUR 758.2 million (Hryszko, 2018.).

Such a rapid development of foreign trade in agri-food products resulted undoubtedly from Polish accession to the EU and the abolition of restrictions on trade with other Member States. It was of much significance to adjust the food industry to market economy conditions and the operation of producers within the single European market. After the accession, there was a constant development of food industry enterprises, and recapitalization that led to increasingly higher positions on the local, national and international markets. Market development has increased the competitive advantage of Polish food producers and improved indicators of international competitiveness (Juchniewicz 2014, Szczepaniak 2017, Tereszczuk, 2018).

The competitive position of Polish producers on the EU market has improved, as measured by selected indicators of international competitive position, i.e. OE - export orientation indicator and TC - export coverage rate. The most competitive products were meat, fish, fruit and vegetable, dairy, confectionery, food concentrates, non-alcoholic beverages and tobacco (Szczepaniak, 2017). This positive aspect of improving the competitiveness of the food industry in Poland results mainly from simple comparative advantages which have a source primarily in price advantages and relatively low processing costs (Juchniewicz 2014). In addition, the quality of Polish food, which meets the demand of Europeans for pro-health and natural products, is increasingly appreciated (Fryc, 2018).

\section{Materials and methods}

The purpose of the work was to analyze the innovation of enterprises processing products of animal origin, in the context of their competitiveness on the global market.

Quantitative research was carried out between December 2013 and January 2014 within the group of 230 companies representing the animal products market. The research tool was a questionnaire consisting of two parts: questions regarding the subject and respondents' particulars.

Selection of entities participating in the research was based on the code List of Classification of Business Activities in Poland (PKD) from 2007, compatible with Statistical Classification of Economic Activities of the European Union, according to which industrial companies are selected companies from Section C - Manufacturing, Unit 10 Food products manufacture. To detailed research companies described in PKD as $1011 \mathrm{z}$ (processing and preserving of meat excluding poultry - 147), 1012z (processing and preserving of poultry - 47) and $10.51 \mathrm{z}$ (processing of milk and cheese production - 36) were selected. The samples for the research were selected purposefully; the main determining characteristic was the size of the company based on the number of employees. Table 1 shows the profiles of participating companies. 


\section{A. Tul-Krzyszczuk, P. Jankowski}

According to our methods, among the chosen entities were companies of different sizes based on number of employees. Among them were micro, small, medium and large meat companies. Small companies employing from 10 to 49 people were the most numerous $(57,8 \%)$, medium-sized companies employing from 50 to 249 people comprised $23,5 \%$ of the group. Participation of micro companies was very interesting; they usually were family businesses, and comprised $13 \%$ of the group.

Table 1. Structure of participating companies $(\mathrm{N}=230)$

\begin{tabular}{|c|c|c|c|}
\hline Characteristic of the sample & Division & Number & Percentage $[\%]$ \\
\hline \multirow{3}{*}{ Branch } & Pork and beef processing & 147 & 63,9 \\
\hline & Poultry processing & 47 & 20,4 \\
\hline & Milk processing & 36 & 15,7 \\
\hline \multirow{4}{*}{ Number of employees } & $1-9$ & 30 & 13,0 \\
\hline & $10-49$ & 133 & 57,8 \\
\hline & $50-249$ & 54 & 23,5 \\
\hline & 250 and more & 13 & 5,7 \\
\hline \multirow{4}{*}{ Time of operating on Polish market } & up to 5 years & 34 & 14,8 \\
\hline & $5-9$ years & 35 & 15,2 \\
\hline & $10-15$ years & 42 & 18,3 \\
\hline & over 15 years & 119 & 51,7 \\
\hline \multirow{3}{*}{ Form of ownership } & National & 216 & 93,9 \\
\hline & Foreign & 6 & 2,6 \\
\hline & Mixed & 8 & 3,5 \\
\hline \multirow{4}{*}{ Area of core business / market } & Local & 35 & 15,2 \\
\hline & Regional & 85 & 37 \\
\hline & National & 68 & 29,6 \\
\hline & International & 42 & 18,3 \\
\hline \multirow{3}{*}{ Profit and losses in year 2012} & Profit net & 158 & 68,7 \\
\hline & Loss & 33 & 14,3 \\
\hline & Refused to answer & 39 & 17,0 \\
\hline \multirow{6}{*}{$\begin{array}{l}\text { Assessment of financial condition of } \\
\text { company }\end{array}$} & Very good & 5 & 2,2 \\
\hline & Good & 110 & 47,8 \\
\hline & No good nor bad & 89 & 38,7 \\
\hline & $\mathrm{Bad}$ & 15 & 6,5 \\
\hline & Very bad & 1 & 0,4 \\
\hline & Refused to answer & 10 & 4,4 \\
\hline
\end{tabular}

Source: research within the project "Bio-food".

Every second participating meat company had been operating on the market for over 15 years, so they were comparatively a long time on the market.

The vast majority of participants were national (216, comprised $94 \%$ of the group). Foreign capital was present only in six companies. National producers of meat and milk products dominated in the research. Participating companies operated mostly on regional (37\%) and national $(29,6 \%)$ markets. This clearly indicates the character of meat and milk enterprises. In view of a comparatively long operating period on the market (over 15 years) and regional activity, it might be concluded that these are competitive advantages of these producers. It is also interesting to note that every 42 companies declared their main activity as being on the international market.

The financial condition of participating companies was expressed with reported profit or loss in 2012 and with self-evaluation in the questionnaire. Almost 69\% of participants 
declared profit, and only $6,9 \%$ of respondents evaluated their financial condition as bad or very bad. Only five firms evaluated their financial condition as very good. Almost $48 \%$ declared good condition. So it can be assumed that participating companies were in median or good financial condition, although many more showed net profit, which should have resulted in higher self-evaluation.

Detailed statistical analysis was made in order to check the relationship between responses to selected questions from the questionnaire and affiliation of companies to individual groups with different levels of innovation. The non-parametric statistical tests were used: models of ordered polynomial variables, Cronbach's alpha coefficient, Kruskal-Wallis analysis, Tukey's multiple comparison test, test chi2 independence and Wilcoxon test.

\section{Innovative activity of enterprises and its effects in the light of authors' own research}

In a modern, global economy, the key to creating a competitive advantage is the systematic introduction of new or improved technological, technical, marketing and/or organizational solutions. Innovation is now the most important source of a company's success and at the same time a factor of its strategic development (Kociszewski, SzwackaMokrzycka, 2011; Porter, 1990; Schwab, 2012)

Taking into account a number of innovative activities undertaken in the analyzed enterprises in the period from 2010 to 2012, the most often implemented or significantly improved were: new or improved machines, devices or tools; a new product or service; or a new delivery, production or logistics process (e.g. purchase of a purchasing system, transport, trade and accounting). All these activities are within the group of technological innovation (product and process) (Table 2) associated with the change or introduction of a new product into a company's portfolio.

The year 2013 showed a slight slowdown of these activities in favor of marketing innovations. The surveyed companies introduced more changes for aesthetic or other creative modifications (e.g. in appearance, form, shape or packaging), as well as varied pricing strategies and introduced new forms of promotional activities in communication with the client. The dairy industry was outstanding in this respect.

Statistical analysis of individual characteristics of enterprises has shown that the innovativeness of enterprises grows with the number of employees (especially in conducting broad marketing activities) and with the growth of their area of activity (in particular companies with an international scope of activity stand out here). Furthermore, the activity of innovation of the smallest players, especially in the field of technological operations and marketing, has been increasing. There was no significant difference in innovativeness between enterprises with different periods of operation on the Polish market. The above results are confirmed by numerous scientific studies in this area (Fryc, 2018; Juchniewicz 2014; Kociszewski and Szwacka-Mokrzycka, 2011; Lemanowicz, 2013)

The source literature emphasizes the importance of innovation which makes the entity competitive. Enterprises that introduce innovations are more profitable than those that choose not to invest. These companies achieve: reduction of operating costs, diversification and expansion of the products and services offered, improvement of the quality of existing products and services (Avermaetea et al., 2004; Drucker, 1998; Muthusamy, 2009; Porter, 1990). Providing the consumer with innovative products that are attractive to them, ensures 
that the company maintains its position on the market or increases its market share, which leads to an increase in sales revenues, and thus to greater competitiveness. The combination of new technologies and a new production organization enables maximization of production efficiency (Bruchart-Korol and Furman, 2007; Jeznach, 2008).

Table 2. Percentage structure of innovative activities implemented in 2010-2012 and in 2013 among the surveyed enterprises $(\mathrm{N}=230)$, representing meat processing $(\mathrm{N}=194)$ and milk $(\mathrm{N}=36)$ [in $\%$ ]

\begin{tabular}{|c|c|c|c|}
\hline Innovative activities & Division & $2010-2012$ & 2013 \\
\hline \multirow{3}{*}{$\begin{array}{l}\text { IMPLEMENTATION OF NEW OR IMPROVEMENT OF } \\
\text { MACHINERY, EQUIPMENT, TOOLS }\end{array}$} & Total & 57,8 & 36,5 \\
\hline & Meat processing & 56,2 & 35,1 \\
\hline & Milk processing & 66,7 & 44,4 \\
\hline \multirow{3}{*}{$\begin{array}{l}\text { SUCCESSFUL IMPLEMENTATION AND IMPROVEMENT OF A } \\
\text { PRODUCT OR SERVICE }\end{array}$} & Total & 53,0 & 41,3 \\
\hline & Meat processing & 51,0 & 39,7 \\
\hline & Milk processing & 63,9 & 50,0 \\
\hline \multirow{3}{*}{$\begin{array}{l}\text { SUCCESSFULLY INTRODUCING OR SIGNIFICANTLY } \\
\text { IMPROVING THE DELIVERY, PRODUCTION OR LOGISTICS } \\
\text { PROCESS }\end{array}$} & Total & 47,8 & 33,5 \\
\hline & Meat processing & 48,5 & 33,0 \\
\hline & Milk processing & 47,2 & 38,9 \\
\hline \multirow{3}{*}{ IMPLEMENTATION OF A NEW PRICING STRATEGY } & Total & 37,4 & 41,7 \\
\hline & Meat processing & 37,1 & 41,2 \\
\hline & Milk processing & 38,9 & 44,4 \\
\hline \multirow{3}{*}{$\begin{array}{l}\text { MARKET (MARKETING) RESEARCH WAS CONDUCTED TO } \\
\text { INTRODUCE A NEW PRODUCT OR SERVICE }\end{array}$} & Total & 30,4 & 21 \\
\hline & Meat processing & 28,0 & 20,6 \\
\hline & Milk processing & 33,3 & 25,0 \\
\hline \multirow{3}{*}{$\begin{array}{l}\text { THE INTRODUCTION OF OTHER SIGNIFICANT CHANGES IN } \\
\text { NON-TECHNOLOGICAL INNOVATION (E.G. CHANGE THE } \\
\text { AESTHETIC IN APPEARANCE, FORM, SHAPE OR PACKAGING, } \\
\text { NOT SEASONAL, NOT ROUTINE) }\end{array}$} & Total & 35,2 & 33,9 \\
\hline & Meat processing & 34,0 & 28,9 \\
\hline & Milk processing & 41,7 & 61,1 \\
\hline \multirow{3}{*}{$\begin{array}{l}\text { IMPLEMENTATION OF A NEW FORM OF PROMOTIONAL } \\
\text { ACTIVITIES }\end{array}$} & Total & 30,4 & 35,2 \\
\hline & Meat processing & 29,9 & 33,5 \\
\hline & Milk processing & 33,3 & 44,4 \\
\hline \multirow{3}{*}{$\begin{array}{l}\text { IMPLEMENTATION OF A NEW OR SIGNIFICANTLY CHANGED } \\
\text { BUSINESS STRATEGY }\end{array}$} & Total & 30,9 & 23,9 \\
\hline & Meat processing & 33,0 & 24,2 \\
\hline & Milk processing & 22,2 & 25,0 \\
\hline \multirow{3}{*}{ NEW, CHEAPER SOURCE OF SUPPLY } & Total & 32,2 & 28,7 \\
\hline & Meat processing & 32,0 & 27,3 \\
\hline & Milk processing & 33,3 & 36,1 \\
\hline
\end{tabular}

Source: research within the project "Bio-food".

The results of the our own research provide confirmation of these statements, where the majority of enterprises operating on the animal products market have noticed the effects of introducing innovations (as presented in Table 3). They were not very spectacular achievements, because they oscillated at the level of up to $10 \%$ or from 10 to $30 \%$. Thanks to innovations, meat industry entrepreneurs increased: sales revenues, market shares, production capacities and improved the quality of manufactured products. Thus, they increased the company's prestige, participation and its competitiveness on the existing or new market. However, the introduction of innovations in dairy companies contributed primarily to: increasing the range and improving the quality of products (services), opening new markets or increasing the share of existing markets and increasing the company's prestige, as well as increasing production capacity (service) and competitiveness. 
Fewer than $1 / 3$ of respondents from the meat and dairy industry did not see the impact of the introduction of the above-mentioned innovations to increase the range of products or services, the production capacity (service) or increased shares on existing or new markets.

Table 3. The effects of introducing innovations in enterprises representing meat processing $(\mathrm{n}=194)$ and milk $(\mathrm{n}=36)[$ in $\%]$

\begin{tabular}{|c|c|c|c|c|c|c|}
\hline \multirow{3}{*}{ EFFECTS } & \multicolumn{2}{|c|}{ No changes } & \multicolumn{2}{|c|}{$0-10 \%$} & \multicolumn{2}{|c|}{$>10 \%$} \\
\hline & \multicolumn{6}{|c|}{ Processing } \\
\hline & Meat & Milk & Meat & Milk & Meat & Milk \\
\hline INCREASING THE RANGE OF PRODUCTS / SERVICES & 28,9 & 25,0 & 39,2 & 52,8 & 32 & 22,2 \\
\hline $\begin{array}{l}\text { OPENING NEW MARKETS OR INCREASING THE SHARE } \\
\text { IN EXISTING MARKETS }\end{array}$ & 24,7 & 30,6 & 38,7 & 50,0 & 36,6 & 19,4 \\
\hline IMPROVING THE QUALITY OF PRODUCTS / SERVICES & 17,5 & 19,4 & 35,1 & 47,2 & 47,5 & 33,4 \\
\hline INCREASING SALES REVENUE & 24,2 & 27,8 & 46,9 & 44,4 & 28,8 & 27,8 \\
\hline INCREASING MARKET SHARE & 28,4 & 36,1 & 43,3 & 41,6 & 28,3 & 22,3 \\
\hline INCREASING PRODUCTION / SERVICES & 26,3 & 30,6 & 41,8 & 30,6 & 32 & 38,9 \\
\hline INCREASING THE COMPANY'S PRESTIGE & 25,8 & 16,7 & 27,8 & 47,2 & 46,4 & 36,1 \\
\hline INCREASING COMPETITIVENESS & 23,2 & 22,2 & 37,1 & 38,9 & 39,7 & 38,9 \\
\hline
\end{tabular}

Source: research within the project "Bio-food".

According to the polynomial variable model, if the company conducted market research to launch a new product or service, more than a $30 \%$ increase in its market share became more likely (as $0.473>0$ ). Similarly, if a company introduced or refined a delivery, production or logistics process, the more than $30 \%$ increase in its market share became likely (since $0.899>0$ ).

On the basis of the full model, it can be concluded that the introduction or significant improvement of the delivery, production or logistics process (since $0.839>0$ ), the implementation of the so-called advanced management techniques (since 0.762>0) and finding new, cheaper sources of supply (because $0.621>0$ ) have a statistically significant impact on the possible increase in market shares as a result of innovations introduced.

The above model was also subjected to a reduction by stepwise regression, obtaining its following form (already with all statistically significant parameters). If the company has introduced or improved the delivery, production or logistics process, the more than $30 \%$ increase in its market share has become more probable (since $0.750>0$ ). If the company has implemented any advanced management techniques, then the more than $30 \%$ increase in its market share has become likely (because 0.980>0) and if the company found a new, cheaper source of supply, the less likely it became the more than $30 \%$ increase in its share in the market ( since $-0.549<0$ ).

\section{Analysis of innovation due to the characteristics of enterprises}

As a scale of innovativeness of enterprises, the question "Please rate the listed activities undertaken in order to make your company stand out on the market by importance" was used, which assessed on a five-point scale basis (i.e. from 1- less important to 5 - the most important), where 15 actions were taken. Responses to this question were characterized by high cohesion. The survey analysis Principal Component Analysis showed no existence of disjoint groups of actions (results not shown) and the Cronbach's alpha coefficient for the ratings of 15 operations was 0.87 . 
Table 3 (the first column of results) presents a comparison of the average of the validity grades of the innovative activities under assessment according to the evaluation companies. The average ratings for 15 activities were compared using Tukey's multiple comparison method. Evaluation of the activities marking containing the same letter did not show a statistically significant difference. According to the results presented, the highestrated activities by enterprises are those related to improving contacts with customers (and contractors), seeking new markets and providing products of higher quality than those of competitors. The activities that were assessed the lowest were related to the promotion, marketing, implementation of quality and safety management systems and research activities.

Table 3. Actions taken in order to distinguish the companies in the market of varying importance in the studied groups of undertakings designated cluster analysis *

\begin{tabular}{|c|c|c|c|c|}
\hline Activities & $\begin{array}{l}\text { Average in } \\
\text { the sample }\end{array}$ & $\begin{array}{c}\text { Group } \\
1 \\
\end{array}$ & $\begin{array}{c}\text { Group } \\
2\end{array}$ & $\begin{array}{c}\text { Group } \\
3 \\
\end{array}$ \\
\hline 1. We strive to build lasting bonds of loyalty with buyers / suppliers & $4,41 \mathrm{a}$ & $4,71 \mathrm{~B}$ & $4,54 \mathrm{~B}$ & $4,12 \mathrm{~A}$ \\
\hline 2. We place great emphasis on customer service & $4,35 \mathrm{a}$ & $4,66 \mathrm{~B}$ & $4,67 \mathrm{~B}$ & $3,95 \mathrm{~A}$ \\
\hline 3. Still we are looking for a new market for our products & $4,26 \mathrm{ab}$ & $4,66 \mathrm{~B}$ & $4,71 \mathrm{~B}$ & $3,71 \mathrm{~A}$ \\
\hline 4. We work directly with customers / partners & $4,17 \mathrm{a}$ & $4,58 \mathrm{~B}$ & $4,65 \mathrm{~B}$ & $4,17 \mathrm{~A}$ \\
\hline 5. We offer products of higher quality than competitors & $4,15 \mathrm{ab}$ & $4,49 \mathrm{~B}$ & $4,46 \mathrm{~B}$ & $3,73 \mathrm{~A}$ \\
\hline 6. We are flexible & $4,03 \mathrm{bc}$ & $4,38 \mathrm{~B}$ & $4,19 \mathrm{~B}$ & $3,69 \mathrm{~A}$ \\
\hline 7. We expand the market for our products / services & $3,73 \mathrm{c}$ & $4,36 \mathrm{~B}$ & $4,15 \mathrm{~B}$ & $3,03 \mathrm{~A}$ \\
\hline 8. We introduce new / innovative products & $3,55 \mathrm{c}$ & $4,16 \mathrm{~B}$ & $4,08 \mathrm{~B}$ & $2,81 \mathrm{~A}$ \\
\hline 9. We vary / expanding assortment of products / services & $3,46 \mathrm{~cd}$ & $4,09 \mathrm{~B}$ & $3,83 \mathrm{~B}$ & $2,79 \mathrm{~A}$ \\
\hline 10. We offer products cheaper than competitors, but th & 3,4 & $3,92 \mathrm{~B}$ & $3,35 \mathrm{~A}$ & $3,14 \mathrm{~A}$ \\
\hline 11. We conduct continuous staff training & $3,42 \mathrm{~cd}$ & $4,01 \mathrm{~B}$ & $3,83 \mathrm{~B}$ & $2,76 \mathrm{~A}$ \\
\hline $\begin{array}{l}\text { 12. We increase expenditures on advertising and promotion, we } \\
\text { conduct numerous promotional campaigns }\end{array}$ & $3,14 \mathrm{de}$ & $3,94 \mathrm{~B}$ & $3,65 \mathrm{~B}$ & $2,27 \mathrm{~A}$ \\
\hline $\begin{array}{l}\text { 13. We implement additional quality management systems (QMS) and } \\
\text { security }\end{array}$ & $2,85 \mathrm{ef}$ & $4,03 \mathrm{~B}$ & $2,25 \mathrm{~A}$ & $2,26 \mathrm{~A}$ \\
\hline duct extensive marketing activities & & 3,8 & $2,60 \mathrm{~B}$ & $1,97 \mathrm{~A}$ \\
\hline 15. We conduct extensive research activities & $2,50 \mathrm{f}$ & $3,65 \mathrm{~B}$ & $2,21 \mathrm{~A}$ & $1,76 \mathrm{~A}$ \\
\hline
\end{tabular}

The mean responses in the groups were compared with the average responses in the whole sample tested. The average answers in the sample, for 15 actions, were compared with each other by the Tukey method (letter designations - lower case letters). For each of the actions, groups of companies with matching answers were indicated independently (letter designation - upper case letters).

Source: research within the project "Bio-food".

The growth of the position of Polish food producers on the international arena would not have been possible if they did not achieve competitive advantages over producers from other EU countries, i.e. if they did not offer EU products better and cheaper than the competition offered (Tereszczuk, 2018). Price and quality of the market are included in the basic instruments of competition, facilitating the struggle to win customers on the food market. In addition, this group should also comprise the brand, modern technologies and convenience for the customer distribution network. The elements connected with the relations between entities, i.e. loyalty, professionalism of customer service, timely deliveries or greening processes (Dolata and Hadryjańska, 2013) are also becoming more and more important.

The selected innovation scale was used to divide enterprises into three groups, each group consisted of enterprises with similar innovativeness. The numbers of the designated groups were: 77, 52 and 101, respectively. 
In order to evaluate the innovativeness of enterprises in individual groups, the average of the assessments of the activities examined in the subsequent groups was determined (Table 3) and the averages were compared using the Tukey's multiple comparison method. Groups marked with the same letter did not show a statistically significant difference in the assessment of the validity of a given innovation measure. As for results, Group 1 companies is a group of the most innovative and Group 3 the group of the least innovative. Group 2 is the most innovative in the field of action, however, it is not innovative for the following actions: offer cheaper products than the competition, but the same quality; widely-developed research activity; implementation of additional quality management systems (QMS) and security; broad marketing activities (in the case of this activity, companies from Group 2 can be described as moderately innovative).

The characteristics of selected groups of enterprises are described in Table 4. As shown by the chi-square test, the period of operation on the Polish market was not a differentiating feature of the group. Compared to the entire sample, Group 1 is characterized by an increased share of large companies operating on the international market. Its branch composition is similar to the composition in the entire sample, with a slight excess of poultry processing companies, at the expense of pork and beef meat processing companies. Group 2 is characterized by overrepresentation of enterprises from the milk processing industry and a significantly reduced number of companies processing poultry. In addition, these are mainly companies employing 10-249 employees. Their range of activity has a similar distribution to the distribution in the sample under study. In Group 3 , we see a reduced number of companies processing milk, an advantage of small companies, rarely operating on the international market.

Table 4. Characteristics of designated groups of companies as compared to the characteristics of the sample

\begin{tabular}{l|l|c|ccc}
\hline \multicolumn{2}{c|}{ Characteristics of the sample } & $\begin{array}{c}\text { Total sample } \\
(\mathrm{n}=230)\end{array}$ & $\begin{array}{c}\text { Group 1 } \\
(\mathrm{n}=77)\end{array}$ & $\begin{array}{c}\text { Group 2 } \\
(\mathrm{n}=52)\end{array}$ & $\begin{array}{c}\text { Group 3 } \\
(\mathrm{n}=101)\end{array}$ \\
\hline \multirow{2}{*}{ Processing industry } & meat & 84,3 & 83,1 & 75,0 & 90,1 \\
& milk & 15,7 & 16,9 & 25,0 & 9,9 \\
\hline \multirow{4}{*}{$\begin{array}{l}\text { Number of persons } \\
\text { employed }\end{array}$} & up to 9 people & 13,0 & 7,8 & 9,6 & 18,8 \\
& $10-49$ people & 57,8 & 50,7 & 57,7 & 63,4 \\
& $50-249$ people & 23,5 & 31,2 & 28,9 & 14,9 \\
Period of operation on & above 249 people & 5,7 & 10,4 & 3,9 & 3,0 \\
\hline \multirow{5}{*}{ the Polish market } & up to 5 years & 14,8 & 16,9 & 11,5 & 14,9 \\
& 5-9 years & 15,2 & 15,6 & 15,4 & 14,9 \\
& $10-15$ years & 18,3 & 18,2 & 19,2 & 17,8 \\
& above 15 years & 51,7 & 49,4 & 53,9 & 52,5 \\
\hline \multirow{5}{*}{ Area of basic activity } & local (city, district) & 15,2 & 6,5 & 15,4 & 21,8 \\
& regional & 37,0 & 28,6 & 36,5 & 43,6 \\
& national & 29,6 & 31,2 & 30,8 & 27,7 \\
& international & 18,3 & 33,7 & 17,3 & 6,9 \\
\hline
\end{tabular}

Source: research within the project "Bio-food".

Table 5 shows the results of a comparison of average grades validity of actions taken in industries processing for meat and milk. The table includes only those activities whose validity rating differed in a statistically significant manner. As the results show, the 
industry of outstanding innovation is the milk processing industry. The research showed that the industry is significantly higher in weight than 4 out of 15 innovative activities. The least innovative industry is the pork and beef meat processing industry, while the poultry meat processing industry is positioned among the rest.

Table 5. Actions taken to distinguish companies on the market, with different importance in the surveyed groups of enterprises from various industries *

\begin{tabular}{l|cc}
\hline \multicolumn{1}{c|}{ Actions } & Meat processing & Milk processing \\
\hline Multiplicity & 194 & 36 \\
We increase expenditures on advertising and promotion, we & 3,07 & 3,53 \\
conduct numerous promotional campaigns & 4,11 & 4,39 \\
We offer products of higher quality than competitors & 3,35 & 3,83 \\
We conduct continuous staff training & 2,64 & 3,33 \\
We conduct extensive marketing activities (e.g. in the field of & 3,64 & 4,19 \\
public relations - PR) & 3,97 & 4,39 \\
We are expanding the market for our products / services & We are flexible &
\end{tabular}

* Group numbers and average answers to the question about activities with statistically significantly different responses according to the Wilcoxon test for pairs of observations.

Source: research within the project "Bio-food".

These results confirm current directions of activity in the Polish agri-food processing sector. The meat industry has been well prepared for the technological leap in recent years. It has invested in a machine park that allows production of the highest class products. Such standards are enforced by the main recipient of the agri-food sector, i.e. retail chains and consumers, as well as the possibility of exporting to international markets. The plants, which invested heavily in modern technologies and optimization of processes with the participation of the workforce, recorded higher revenues. Hence the statement that innovative solutions help to deal with a difficult market. Therefore, apart from the extraliga in the Polish meat industry, i.e. Animex and Sokołów groups, the first league of plants with revenues between PLN 400 and 600 million is being generated. (Jachowski, 2016; Wieczorkiewicz, 2016).

\section{Summary}

The study presents an analysis of the innovative activity of enterprises representing the meat and dairy industry in Poland in the context of building competitiveness on the global market. Based on the results of the research, in the analyzed period from 2010 to 2012, technological (product and process) innovations were most often implemented, and in 2013 the share of introduced marketing innovations increased. The level of innovativeness in the industries was determined. The industry with outstanding innovation is milk processing, the medium-innovative industry - poultry meat processing and the least innovative - pork and beef meat processing. The innovativeness of enterprises grows with the number of employees employed and with the increase in their area of operations (i.e. companies with an international reach).

- Group 1 - the most innovative, with the participation of large companies operating on the international market, with a slight excess of poultry processing companies. The current strategy of action is aimed at increasing or maintaining (at the current level), sales, through 
expanding the market, investments in new technologies and in the permanent assets of the enterprise.

- Group 2 - moderately innovative, with overrepresentation of enterprises employing 10249 employees from the milk processing industry and a significantly reduced number of companies processing poultry. The group is innovative in terms of the majority, but not all activities, i.e. cheaper offer, of the same quality as in competition or marketing (price strategies, promotional activities, etc.). Its current activity is directed at the same factors as in the game. 1 .

- Group 3 - the least innovative, with the advantage of small companies, rarely operating on the international market, mainly from the meat industry.

Most enterprises operating on the animal products market noticed the effects of introducing innovations at the level of approx. $10-30 \%$. Owing to innovations, meat industry entrepreneurs increased: sales revenues, market shares, production capacities and improved the quality of manufactured products. Thus, they increased the company's prestige, participation and its competitiveness on the existing or new market. However, the introduction of innovations in dairy companies contributed primarily to: increasing the range and improving the quality of products (services), opening new markets or increasing the share of existing markets and company prestige, as well as improving the productive (service) capacity, competitiveness and prestige of the market.

The confirmation of the above actions are very good results of foreign trade in agrifood products (including meat and dairy products) and improvement of competitiveness indicators, which prove high international competitiveness of the Polish agri-food sector. The previous source of competitive advantages on the EU and global markets were primarily cost and price advantages. However, in the conditions of European integration and economic globalization, non-price determinants of competitiveness are becoming more and more important, such as: the quality of the offer, more long-lasting relationships with customers and contractors (suppliers), increasing production capacities or seeking new markets.

In this situation, it seems necessary to develop an economic policy that is friendly to entrepreneurs implementing innovations. Its aim should be to stimulate enterprises to become more involved in financing and cooperation with the $\mathrm{R} \& \mathrm{D}$ sector. It is also necessary to improve the institutional infrastructure supporting innovative activity and transfer of knowledge and technologies to enterprises.

\section{Bibliography}

Ambastha, A., Momaya, K. (2004). Competitiveness of firms: review of theory, frameworks, and models. Singapore Management Review, 26(1), 45-61.

Avermaetea, T., Viaenea, J.,Morganb, E.J., Pittsc, E., Crawfordb, N., Mahon, D. (2004). Determinants of product and process innovation in small food manufacturing firms. Trends in Food Science \& Technology, 15, 474-483.

Drucker, P.F. (1998). On the Profession of Management. Boston: Harvard Business Scholl Press.

Dunford, M., Louri, H., Rosenstock, M. (2001). Competition, competitiveness, and enterprise policies, MPRA Paper 29971, University Library of Munich, Germany.

Figiel, Sz. (ed.) (2015). Selected aspects of innovation in the agri-food sector. Warszawa: IERiGŻ - PIB

Flak, O., Głód, G. (2009). Competitiveness of the company. Concepts, definitions, models. Part 1, Wydawnictwo Akademii Ekonomicznej w Katowicach, Katowice. 
Fryc, J. (2018). The export of Polish food is growing like on yeast. Increase by more than 400 per cent. Downloaded 15 October 2018 from: https://businessinsider.com.pl/finanse/handel/eksport-polskiejzywnosci-do-ue/fjwvb97.

Gorynia, M. (2010). Competitiveness in microeconomic terms. In: Gorynia M., Łaźniewska E. Compendium of knowledge on competitiveness. Wydawnictwo Naukowe PWN, Warszawa.

Gorynia, M. (ed.) (2002). A competitive gap at the enterprise level and Poland's accession to the European Union. Wydawnictwo Akademii Ekonomicznej, Poznań.

Hryszko, K. (red.) (2018). Agricultural Market. October 2018, Warszawa: IERiGŻ - PIB.

Jachowski, P. (2016). The meat industry on the trail of innovation. Downloaded 20 October 2018 from: https://www.wiadomoscihandlowe.pl/artykuly/branza-miesna-na-szlaku-innowacji,5417.

Juchniewicz, M. (2014). Trends in the international competitiveness of the food industry of the European Union Member States. Roczniki Naukowe Ekonomii Rolnictwa i Rozwoju Obszarów Wiejskich, 101(1), 31-40.

Kociszewski, M., Szwacka-Mokrzycka, J. (2011). Conditions for the development of the food industry after Poland's accession to the EU. ZN SGGW Problemy Rolnictwa Światowego, 11(2), 67-77.

Lemanowicz, M. (2014). Innovative activity of enterprises in Poland with particular emphasis on the food industry. Roczniki Naukowe Stowarzyszenia Ekonomistów Rolnictwa i Agrobiznesu, 16(6), 307-312.

Lombana, J. (2011). Looking for a distinctive model with which to analyze competitiveness. ACR, 19 (3\&4), $32-45$.

Multański, J. (2018). Raport: Konsolidacja i problemy w branży mięsnej, Think M\&A - Branża Mięsna 2018 (Report: Consolidation and problems in the meat industry, Think M\&A - Meat industry 2018).

Muthusamy, S.K. (2009). Organizational innovativeness: a theoretical review and integration. Social Science Research Network.

OECD (1996). Globalisation and competitiveness: Relevant Indicators, „STI Working Papers”, np. 16/1996, Paris.

Porter, M.E. (1990). The Competetive Advantage of Nations. With a new introduction. The Free Press Ltd. New York.

Schwab, K. (2012). Global Competitiveness Report 2012-2013", World Economic Forum, September 2012. Downloaded 20 October 2018 from: http://reports.weforum.org/global-competitivenessreport-2012-2013.

Szajner, P. (ed.) (2018). Handel zagraniczny produktami rolno-spożywczymi (Foreign trade in agri-food products). Nr 48/2018, Warszawa: IERiGŻ - PIB

Szczepaniak, I. (2014). Konkurencyjność polskiego przemysłu spożywczego na rynku krajowym i międzynarodowym - wybrane elementy (Competitiveness of the Polish food industry on the domestic and international market - selected elements). Roczniki Naukowe Stowarzyszenia Ekonomistów Rolnictwa i Agrobiznesu, 16(4), 281-287.

Szczepaniak, I. (2017). Międzynarodowa konkurencyjność przemysłu spożywczego w okresie członkostwa Polski w Unii Europejskiej. Bułgarsko-Polska Konferencja Naukowa pt. Rolnictwo i obszary wiejskie Polski i Bułgarii we Wspólnej Polityce Rolnej 2014-2020 i po roku 2020 (International competitiveness of the food industry in the period of Poland's membership in the European Union. Bulgarian-Polish Scientific Conference "Agriculture and rural areas of Poland and Bulgaria in the Common Agricultural Policy 20142020 and beyond 2020"), Sofia, 12-13 October 2017.

Szopik, K. (2007). Innowacyjność przedsiębiorstw w aspekcie wzrostu konkurencyjności gospodarki (Innovativeness of enterprises in the aspect of increasing the competitiveness of the economy). ZN US Ekonomiczne Problemy Ustug, 453(8), 295-300.

Tacken, G.M.L., Banse, M., Batowska, A., Gardebroek, C., Turi, K.N., Wijnands, J.H.M., Poppe, K.J. (2009). Competitiveness of the EU Dairy Industry. Lei Wageningen UR, The Hague.

Tereszczuk, M. (2018). Konkurencyjność polskiego eksportu rolno-spożywczego. (Competitiveness of Polish agrifood export). Downloaded 20 October 2018 from: http://www.eksporterzy.org/documents/2018-0321_prezentacja/M_Tereszczuk_Konkurencyjnosc.pdf

Tłuczak, A. (2017). Konkurencyjność przestrzenna rolnictwa w krajach Unii Europejskiej (Spatial competitiveness of agriculture in the European Union countries). Problemy Rolnictwa Światowego, 17(3), 279-285.

Wieczorkiewicz, R. (2016). Branża mięsna stawia na innowacje (The meat industry is committed to innovation). Downloaded 20 October 2018 from: http://www.portalspozywczy.pl/mieso/wiadomosci/branza-miesnastawia-na-innowacje, $127770 . \mathrm{html}$.

For citation:

Tul-Krzyszczuk A., Jankowski P. (2019). The Impact of Innovation on the Global Competitiveness of Polish Meat and Dairy Enterprises. Problems of World Agriculture, 19(1), 120-132; DOI: $10.22630 /$ PRS.2019.19.1.11 